\title{
Implementation of Activity Based Costing System in Making Effort to Determine The Tariff of Operation Action (Case Study In Surabaya Royal Hospital)
}

\author{
Nanik Kustiningsih \\ School of Economic, STIE Mahardhika, Indonesia \\ Soesilawati Soema Atmadja \\ School of Economic, STIE Mahardhika, Indonesia \\ Ois Patmana \\ School of Economic, STIE Mahardhika, Indonesia
}

\begin{abstract}
The purpose of this study is to determine whether the application of activity-based costing system can show a more accurate resource allocation at Royal Hospital Surabaya . As well as a comparison tool with operating rates that has been established so far, especially in its application to a hospital that its orientation two goals that is community service and profit balance. This research was conducted at Royal Hospital Surabaya. The method used is descriptive method that is calculate the tariff of hospital operation action at this time, set cost method based on activity based costing, then compare tariff of operation action based on activity based costing with its realization. The results showed that from the calculation of the tariff of the operational action by using activity-based costing, if it is compared with the tariff used by the hospital, activity-based costing gives greater results for small operation actions and gives smaller results for medium and large operations. This is due to the overhead cost of each product. In activity-based costing, the overhead cost of each product is charged to many cost of drivers. So in activity-based costing, has been able to allocate the cost of activity to each operational action based on the consumption of each activity
\end{abstract}

Key word: Activity-Based Costing, cost driver

\section{INTRODUCTION}

The main task of the hospital is to provide medical services, care, and health services. In providing health services, hospital gets income from the services and facilities given, one of them is the operation action services, where the income from the services is obtained from the tariffs that should be paid by the service user or the patient. The tariff determination of this operation is a very important decision, because it can affect the profitability of the hospital. Based on the above conditions, the hospital is required to be able to utilize technology and experts in the field of health, communications, information, and the field of transportation that can support health services so as to make the operational costs that is spent by hospital becomes big that will affect high tariff for operation action.

To control costs, the hospital needs an appropriate accounting system, especially the calculation method for cost determination to produce accurate cost information related to the cost of service activity. The calculation of the basic cost is initially applied in a manufacturing company, but in its development the cost of goods has been adapted by the company of service, a trading company, and a nonprofit sector. In Article 3 of Decree of the Minister of Health Number 1165 / Menkes / SK / 2007 concerning arrangement of tariff pattern of Hospital of 
Public Service Agency(PSA) needs to be adjusted with the development and need of health service. About setting the Public Servive Agency tariff pattern of the Hospital includes activities that are charged with tariff, tariff component, tariff calculation pattern, and revenue management of Public Service Agency of the hospital. This fact shows that the government has realized the importance of tariff calculation included in the health care sector. Two contradictory matters require hospital management to be able to set the right tariff so that the two goals can be achieved simultaneously.

As science developed in the early 1900s, a cost-based pricing system was established based on activities designed to overcome cost distortions. This accounting system is called Activity Based Costing $(\mathrm{ABC})$. In the $\mathrm{ABC}$ method, the incidence of costs is caused by the activity produced by the product. This approach uses cost drivers that are based on activitis which generate the cost and would be better if applied to companies that produce product diversity. The purpose of this study is to raise the topic of activity-based costing system (ABC) which relates to one way to calculate or classify the costs that can be used as guidance tariff of hospital costs especially in the field of operation at the Royal Hospital one of the private hospital located in Surabaya.

\section{Definition of Cost}

\section{LITERATURE REVIEW}

Cost accounting is the process of recording, classifying, summarizing, and presenting the costs of making and selling products or delivering services, in particular ways, and interpreting the results. (Surjadi, 2013: 1)

According Syaifullah (2014: 10) In cost accounting known as cost and expense. Cost or commonly referred to as a fee is a prerequisite exchange rate or sacrifice made to obtain a benefit. Where the period is more than one year because it is capital expenditure (capital expenditure). The amount of rupiah spent in large amounts.

While the expense or so-called expense, represents a decrease in economic benefits in an accounting period in the form of an outflow of assets, or the occurrence of liabilities resulting in a decrease in equity, which does not involve the division of investors. The period is less than one year because it is a revenue expenditure (revenue expenditure). And the money issued relatively small.

According to Bustami and Nurlela (2012: 3) Cost, (cost) has not expired, and is classified as assets included in the balance sheet. Example:

1) Supplies of raw materials

2) Inventory of product in process

3) Product inventory complete

4) Supplies or unused assets

While Expenses (Expense) is a cost that has given benefits and now it has run out. Unearned costs that can give benefits in the future are classified as assets. This fee is included in the Profit and Loss, as a deduction from income, Example:

1) Depreciation expense

2) Marketing expense

3) Expenses classified as operating expenses. 


\section{Traditional Cost Accounting and its limitations}

According Mulyadi (2014: 196) traditional cost accounting system calculate the cost of the production as a component products cost. In addition, traditional cost accounting systems only provide detailed information about production costs, costs incurred in the production. Production costs are divided into two categories: (1) direct production costs and (2) indirect costs of production. Direct production costs are production costs that can be charged directly to a particular product. Indirect production costs can not be charged directly to a particular product.

Therefore, in the traditional cost accounting system, product cost consists of 3 elements: (1) raw material cost (RMC), (2) direct labor cost (DLC), (3) factory overhead cost (FOC). RMC and DLC is a direct cost so as not to cause problems loading on the product. Loading RMC and DLC can be done accurately by using direct tracking or driver tracking. However, loading a FOC creates a problem. This is because FOC has no input-output relationship that can be physically observed. Therefore, FOC loading must be based on searching the driver and allocation.

In a traditional cost accounting system only used drivers' activity in unit-level to charge the FOC on the product. The unit-level activity of drivers are the factors that cause the change of cost in accordance with the changes in the product unit in production. The use of unit-level driver costs to charge the FOC on products assumes that the overhead consumed by the product has a very high correlation with the number of units in production. Examples of unitlevel drivers are: (1) units in production, (2) percentage of RMC, (3) percentage of DLC, (4) direct working hours, and (5) hour machine.

Traditional cost accounting systems based on single tariff of FOC and department of FOC fit only in traditional manufacturing environments and domestic level competition. However, traditional cost systems create cost distortions when used in advanced manufacturing environment and global level competition. The environment of advanced manufacturing is an environment that is characterized by sharp and typically global competition, continuous improvement, total customer satisfaction, and advanced technology. Companies operating in an advanced manufacturing environment should use new strategies to achieve excellence. The cost accounting system used to charge a fee must be changed with a system compatible with the environment by using $\mathrm{ABC}$. If the cost system is not altered, there will be too high distortion (cost overstated or cost overrun) for large-volume products and low cost (cost understated or cost under run) for a product with a small volume

\section{Definition of Activity Based Costing}

According to (Armanto 2012: 237) ABC is "a method of measuring the cost of products or services based on the cost accumulation of activities or activities arising in relation to the production or service. Cost calculations based on activity are product cost calculations based on actual activity of input sacrifice to obtain output. (Purwanti and Darsono Prawironegoro, 2013: 43).

Activity Based Costing system is an activity-based costing system, in general ABC uses a twostage approach that is almost the same but more common than the system of tarditional cost. Traditional cost systems use departments and actual cost centers to define a set of costs to accumulate and distribute costs. The $\mathrm{ABC}$ system does not use cost centers, but uses its activities to accumulate costs. The development of ABC begins by asking what activities are being carried out by the department's resources. It then allocates the resource load to the activity based on some of the many resources used by each of those activities. The ABC system not only increases the thoroughness of costing, but also provides information on the cost of 
various activities to enable management to focus on activities that provide opportunities for cost savings by simplifying activities, carrying out activities with more efficiently, and eliminates non value-added activities.

According to Stephanie (2008: 5) steps in development of an ABC system there are four steps to implementing ABC: 1) Identify activities, 2) Assign resource cost to activities, 3) identify outputs, 4) Assign activity costs to outputs. In the first stage, costing based on activity involves the following four steps: (1) classification of various activities, (2) associating various costs with various activities, (3) determination of homogeneous cost pools, and (4) determination of pool rate.

\section{Difference between ABC system with Traditional system}

As mentioned before, a conclusion can be drawn about the difference between ABC systems and traditional cost accounting. In general, the difference between $\mathrm{ABC}$ systems and traditional cost accounting is the number of measures of activity level. ABC uses more than one measure of activity level whereas traditional cost accounting uses only one measure of activity level ie the unit level measure as a basis for allocating overhead to output.

According to Riki (2011: 6) conventional cost system is less able to meet management needs in an accurate cost calculation, especially if it involves considerable indirect production costs and product diversity. Traditional accounting systems are used to determine product costs for extension financial statements. ABCsystem is used to determine the product and cost for a special report to the manager

\section{Hospital Definition and Hospital Accounting}

Understanding the hospital according to Regulation of the Minister of Health of the Republic of Indonesia No. 340 / MENKES / PER / III / 2010 are: "Hospitals are health services institutions that provide full range of personal health services providing inpatient, outpatient and emergency care services". From the above understanding, the hospital conducts several types of services including medical services, medical support services, care services, rehabilitation services, prevention and improvement of health, as a place of education and or medical training and medical, as a place of research and development of science and technology in health as well as to avoid the risks and health disturbances as intended, so that it is necessary condut healthy hospital environment in accordance with health requirements. Based on its ownership, Law No. 44 of 2009 on Hospital in Indonesia into two types, namely:

1. Public hospitals that are government-run hospitals (including local government) and other non-profit legal entities include:
a. The hospital belongs to the Ministry of Health
b. Hospital owned by Provincial Government
c. Hospitals belonging to Regency / City Government
d. The hospital belongs to the Indonesian National Army (TNI)
e. The hospital belongs to the Police of the Republic of Indonesia (Polri)
f. Hospitals belonging to Departments outside the health department (including state- owned companies such as Pertamina).

2. Private hospitals, ie hospitals run by legal entities with the purpose of profit in the form of limited companies or company, include:

a. The hospital belongs to the foundation 

b. Hospitals belong to the company
c. Hospital owned by Investment (domestic and abroad)
d. Hospitals belong to other legal entities.

In terms of service, private hospitals should also be recognized as having the role of creating a healthy Indonesia in 2010. If the quality and the system of private hospital services are reviewed in terms of fulfilling the demands and desires of consumers or patients, many private hospitals prioritise the services. Besides the quality of service, medical support equipment is also more sophisticated and modern compared to government hospital has. Hartono (2010: 5). To achieve all of them need a very much funds. Therefore, the better quality and service in private hospitals, the more expensive the patient should pay. But with that alone sometimes the hospital has not been able to cover its operational needs.

So the management of private hospitals should seek other alternative to increase revenue and allocate funds as needed. Fund accounting applications can also be seen in accounting practices in the hospital. However, it should be realized that not all hospitals are non-profit organizations. Some hospitals are operated as earnings-seeking companies, some even selling their shares in the stock market. In the case of profit-oriented hospitals, the accounting standards followed are the financial accounting standards used for the commercial sector

\section{RESEARCH METHODS}

The type of research used by the authors is qualitative research. which are descriptive and tend to use analysis and further highlight the process and meaning. Population is the whole subject of research, Arikunto (2010: 173). In this study population is the tariff of operational actions that are distinguished according to the risks of small operations, moderate operations and major operations in classes VIPs, I, II, and III.

The sample used by the researcher is a purposive sample that is the technique of determining the sample with certain considerations (Sugiyono, 2011: 68). That is the operational action tariff that is distinguished according to the risks, that is small, medium and major operations in class III

Activity Based Costing System is the information system that is oriented on providing complete information about activities to enable companies to manage activities to determine the cost of products accurately.

Traditional accounting system is an information system that culculates the cost of the production stage as a component the product cost and focuses on the cost of production. The operating tariff is a nominal amount or price in rupiah that has been made in accordance with the standard of tariff determination in such a way, based on the Law and the Minister of Health's decree. Then it is the obligation to be paid by the patient who has performed the surgery

\section{RESEARCH RESULT}

\section{Calculation of the cost of providing operating room services using traditional cost accounting}

To determine the cost of operating room service provision, Royal Hospital Surabaya uses the traditional cost, that is by using direct labor hours for each operation handling, as the cost driver for the indirect costs incurred in the operating room unit. The calculation of the cost is done by adding up all indirect costs to the operating room unit, then dividing the total indirect costs by direct labor hours for each type of operating action. The direct labor hours used are 
less than 1 hour, over 2 hours and over 3 hours, for each type of small, medium, and major operation. The number of direct hours spent for 2014 is 3,427 hours. The amount is obtained from the calculations presented in the following table

Table 4.1 Rating of direct labor hours In operating room units for 2014

\begin{tabular}{|c|c|c|c|c|}
\hline No & catagory & $\begin{array}{c}\text { Number } \\
\text { istimation }\end{array}$ & Labor hour & $\begin{array}{c}\text { Labor hour } \\
\text { numerr }\end{array}$ \\
\hline 1 & Operation & Pasient (A) & Diretc (B) & Direct (AxB) \\
\hline 2 & Minor operation & 608 & 1 & 608 \\
\hline 3 & Medium operation & 832 & 2 & 1.664 \\
\hline & Major operation & 385 & 3 & 1.155 \\
\hline
\end{tabular}

Source : Royal Hospital Data

The indirect cost allocated to the operating room units for 2014 is Rp. 1,061,300,105. Details of these costs can be seen in the following table

Table 4.2 Indirect cost budget in operating room units for 2014

\begin{tabular}{|r|l|r|}
\hline No & Kinds of cost & total \\
\hline 1 & Salary \& allowance & $460,460,494$ \\
\hline 2 & Overtime & 6.300 .000 \\
\hline 3 & Office uniform & 2.100 .000 \\
\hline 4 & Employees' treatment & 2.520 .000 \\
\hline 5 & Consumption/snack & 10.950 .000 \\
\hline 6 & pension cost & 31.000 .000 \\
\hline 7 & Lebaran day allowance & 30.000 .000 \\
\hline 8 & Electricity & 18.069 .810 \\
\hline 9 & Water & 4.542 .120 \\
\hline 10 & Telephone, fax \& internet & 7.347 .674 \\
\hline 11 & Stationery \& printing & 2.284 .591 \\
\hline 12 & Household material & 30.456 .158 \\
\hline 13 & Reduction of assets & 98.463 .067 \\
\hline 14 & Maintenance for assets & 121.675 .900 \\
\hline 15 & Maintenance for building & 125.360 .920 \\
\hline 16 & Incentive & 4.200 .000 \\
\hline 17 & Appraisal & 1.000 .000 \\
\hline 18 & Training & 25.000 .000 \\
\hline 19 & Office travel & 36.615 .880 \\
\hline 20 & Recreation & 7.743 .696 \\
\hline 21 & To entertain guest/meeting & 1.830 .500 \\
\hline 22 & Oxygen & 33.379 .295 \\
\hline & Total & $\mathbf{1 . 0 6 1 , 3 0 0 , 1 0 5}$ \\
\hline
\end{tabular}

Source : Royal Hospital Surabaya. 
From the above data, the cost of providing operating room services, can be calculated as follows:

Indirect tariff $=\mathrm{Rp} \quad 1.061,300.105$

$=$ Rp. 309.697 .8

Table 4.3 Indirect cost calculations on operating room units for 2014

\begin{tabular}{|c|l|c|c|c|}
\hline No & Kinds of operation & Indirect Cost & TKL & Total \\
\hline 1 & Minor Operation & 309.687 .8 & 1 & 309.687 .8 \\
\hline 2 & Medium Operetion & 309.687 .8 & 2 & 619.375 .6 \\
\hline 3 & Major Operation & 309.687 .8 & 3 & 929.063 .4 \\
\hline
\end{tabular}

\section{Calculation of the cost of providing operating room services using $A B C$}

The ABC system is a cost calculation system that charges the cost to products or services based on resource consumption caused by activity. Implementation of the ABC system will result to the burden of cost to products or services more accurate than conventional accounting, since the $A B C$ system uses more cost drivers The cost of providing operating room service by using the $\mathrm{ABC}$ system is done by stages as the following:

\section{Activity identification}

After identifying activities that incur indirect costs on the operating room unit, the next step is to classify the activities into a level of group activity. The level of activity in operating room unit, among others:

\section{a) Unit-level activity}

Unit-level activity is an activity performed every time unit of operation action service is performed. The amount or cost caused by this activity is influenced by the number and duration of one unit of operation performed. Indirect costs groups caused by unit level activities, among others: overtime costs, water costs, incentive costs and oxygen costs.

\section{b) Facility level activity}

Facility level activity is an activity undertaken to sustain the process of providing operational action services. Big or small of the costs incurred by this activity is not influenced by the number or duration of one unit of operation services carried out by indirect cost groups that caused by the facility level activity, among others: salary and allowances, clothing costs, employee treatment,Lebaran day fees, consumption / snack fees, severance costs, telephone expenses, stationery and printing costs, and so on. To clarify the above description, the following table presents an indirect cost budget summary of the operating room units for 2014 
Table 4.4 Summary of indirect cost budget on operating room units for 2014

\begin{tabular}{|l|l|}
\hline The cost based on activity level & Total \\
\hline Activity unit level & \\
\hline Overtime & 6.300 .000 \\
\hline Electricity & 18.069 .810 \\
\hline Water & 4.542 .120 \\
\hline Incentive & 4.200 .000 \\
\hline Oxygen & 33.379 .295 \\
\hline Activiti level facility & 66.491 .225 \\
\hline Salary allowance & 460.460 .494 \\
\hline Clothing & 2.100 .000 \\
\hline Employees' treatment & 2.520 .000 \\
\hline Consumption/snack & 10.950 .000 \\
\hline Pension cost & 31.000 .000 \\
\hline Lebaran allowance & 30.000 .000 \\
\hline Water & 4.542 .120 \\
\hline Telephone & 7.347 .674 \\
\hline Stationery and printing & 2.284 .591 \\
\hline Household material & 30.456 .158 \\
\hline Reduction of asseets & 98.463 .067 \\
\hline Maintenance for assets & 121.675 .900 \\
\hline Maintenance for building & 125.360 .920 \\
\hline Recreation & 7.743 .696 \\
\hline Appraisal & 1.000 .000 \\
\hline Training & 25.000 .000 \\
\hline Office traveling & 36.615 .880 \\
\hline Indirect cost total & \\
\hline & \\
\hline
\end{tabular}

\section{Determination of the homogeneous cost pool, and the cost driver of each group of homogeneous costs}

The homogeneous cost group is a set of indirect costs related to the activities performed, and the various costs can be explained by a single cost driver. Based on the activities identified in the previous stage, at this stage cost groupings can be grouped into homogeneous cost groups, as well as the determination of cost drivers for each group of homogeneous costs. Determination of the homogeneous cost group, along with the cost drivers of each homogeneous cost group, can be seen in the following table: 
Table 4.5 Determination of homogeneous cost groups

Homogeneous cost groups and the cost driver

\begin{tabular}{|c|c|c|}
\hline \\
\hline \multirow{2}{*}{\multicolumn{3}{|c|}{$\begin{array}{l}\text { Homogeneous cost groups } \\
\text { Cost pool } 1\end{array}$}} \\
\hline & & \\
\hline overtime & & 6.300 .000 \\
\hline Electricity & \multirow{6}{*}{$\begin{array}{c}\text { The number of } \\
\text { Labor hour }\end{array}$} & 18.069 .810 \\
\hline Water & & 4.542 .120 \\
\hline Oxygen & & 33.379 .295 \\
\hline Total of cost pool 1 & & 62.291 .225 \\
\hline \multicolumn{2}{|l|}{ Cost pool 2} & \\
\hline Salary allowance & & 460.460 .494 \\
\hline Clothing & & 2.100 .000 \\
\hline Employees' treatment & & 2.520 .000 \\
\hline Consumption/snack & & 10.950 .000 \\
\hline Pesion cost & & 31.000 .000 \\
\hline Lebaran allowance & & 30.000 .000 \\
\hline Training & & 25.000 .000 \\
\hline \multicolumn{2}{|r|}{ Of employees } & \\
\hline Recreation & & 7.743 .696 \\
\hline Office traveling & & 36.615 .880 \\
\hline Total of cost pool 2 & & 607.390 .079 \\
\hline \multicolumn{3}{|l|}{ Cost pool 3} \\
\hline Telephone & & 7.347 .674 \\
\hline Stationery and printing & \multirow{9}{*}{$\begin{array}{c}\text { The number of } \\
\text { patients }\end{array}$} & 2.284 .591 \\
\hline Household material & & 30.459 .158 \\
\hline Reduction of assets & & 98.463 .067 \\
\hline Maintenance of assets & & 121.675 .900 \\
\hline Maintenance of building & & 125.360 .920 \\
\hline Incentive & & 4.200 .000 \\
\hline Entertaining guest/meeting & & 1.830 .500 \\
\hline Total of cost pool 3 & & 391.618 .810 \\
\hline Total of indirect cost & & 1.061 .309 .105 \\
\hline
\end{tabular}

Source : Data obtained by writer

\section{Determination of cost group tariff (cost pool tariff)}

The cost group rate is the indirect cost rate per unit cost driver, which is calculated for a group of activities. The cost group tariff is calculated by the formula: the total indirect cost of a particular activity group, divided by the cost driver of the activity group. The following table presents the calculation of cost group tariff.

Table 4.6 calculation of cost group tariff

\begin{tabular}{|c|c|c|c|}
\hline Cost & Total cost & \\
\hline pool & $\begin{array}{c}\text { Total cost every cost } \\
\text { pool }\end{array}$ & driver & Cost pool rate \\
\hline & $(\mathrm{A})$ & $(\mathrm{B})$ & (A.B) \\
\hline 1 & Rp 62.291.225 & 3.427 & 18.176 .60 \\
\hline 2 & Rp. 607.390.070 & 3.650 & 166.408 .24 \\
\hline 3 & Rp. 391.618.810 & 1.825 & 214.585 .65 \\
\hline
\end{tabular}

Source : Data obtained by writer 
Value of Total cost driver in the above table, obtained by the calculation presented in the following table

Table 4.7 Calculation Total cost driver

\begin{tabular}{|l|c|c|c|c|c|}
\hline Catagory of & Total & Direct Labor & Total hours & employees & Total of \\
\hline Operation & Patients & Hour & Of direct & & employees \\
\hline & estimation & & labor & & \\
\hline & $(\mathrm{A})$ & $(\mathrm{B})$ & (AXB) & (C) & (AXC) \\
\hline & & & & & \\
\hline Minor operation & 608 & 1 & 608 & 2 & 1.216 \\
\hline Medium operation & 832 & 2 & 1.664 & 2 & 1.664 \\
\hline Major operation & 385 & 3 & 1.155 & 2 & 770 \\
\hline Total & 1.825 & & 3.427 & & 3.650 \\
\hline
\end{tabular}

\section{Source : Data obtained by writer}

Table 4.7 in column (B) indicates that in order to perform one minor operation, medium operation, and major operation, 1 hour, 2 hour and 3 hours direct labor is required. In column (C), it indicates that to perform one minor, medium and major operation action required each of the 2 employees who acted as a nurse for minor operating room or an operations assistant.

\section{Cost tracking of each group}

At this stage, the cost of each cost group is traced to each service provider for operation action, using the formula: cost of group tariff, multiplied by the total cost driver consumed. The calculation of the cost of providing operating room services, for the category of minorl, medium, and major operations can be seen in each table below

Table 4.8 Calculation of cost of services for operating room

\begin{tabular}{|l|l|c|c|c|}
\hline No & Operation service & Cost pool rate & Total cost & Total \\
\hline & & & driver & Indirect cost \\
\hline & & $(\mathrm{A})$ & $(\mathrm{B})$ & (AXB) \\
\hline 1 & & 18.176 .60 & 1 & 18.176 .60 \\
\hline 2 & Minor operation & 166.408 .24 & 2 & 332.816 .48 \\
\hline 3 & & 214.585 .65 & 1 & 214.585 .65 \\
\hline
\end{tabular}

The cost of providing operation room service $\quad 565.578 .73$

\begin{tabular}{|l|l|c|c|c|}
\hline 1 & & 18.176 .60 & 2 & 36.353 .2 \\
\hline 2 & Medium operation & 166.408 .24 & 2 & 332.816 .48 \\
\hline 3 & & 214.585 .85 & 1 & 214.585 .65 \\
\hline
\end{tabular}

The cost of providing operation room service $\quad 583.755 .33$

\begin{tabular}{|l|l|l|l|c|}
\hline 1 & & 18.176 .60 & 3 & 54.529 .80 \\
\hline 2 & Major operation & 166.408 .24 & 2 & 332.816 .48 \\
\hline 3 & & 214.585 .65 & 1 & 214.585 .85 \\
\hline \multicolumn{2}{|c|}{ The cost of providing operation room service } & 601.931 .93 \\
\hline
\end{tabular}

Source : Data made by writer

DISCUSSION

Based on the results of the previous analysis, then compared the results of the calculation of the cost of operating services operations according to traditional cost accounting and calculation results according to $\mathrm{ABC}$ system. Comparison between the calculation results 
according to traditional cost accounting, with the calculation results according to $\mathrm{ABC}$ system, can be seen in the following table:

Table 5.1 Comparison of cost of operation service for operational action according to traditional cost of accounting, and $A B C$ system.

\begin{tabular}{|c|c|c|c|}
\hline Catagory of oneration & Traditional & $\mathrm{ABC}$ Suctom & differance \\
\hline Operation cost & $\begin{array}{l}\text { Accounting cost } \\
\text { (Rp) }\end{array}$ & $(\mathrm{Rp})$ & $(\mathrm{Rp})$ \\
\hline Direct cost & 555.493 & 555.493 & 0 \\
\hline \multicolumn{4}{|l|}{ The cost of material used } \\
\hline The cost of doctor's service & $2 . .112 .500$ & 2.112 .500 & 0 \\
\hline \multicolumn{4}{|l|}{ Anesthesia \& nurse fo M.O } \\
\hline Indirect cost & 309.687 .8 & 565.576 .73 & $(255.890 .93)$ \\
\hline Every operation action cost & 2.977 .680 .8 & 3.233 .571 .73 & $(255.890 .93)$ \\
\hline Total patients & 608 & 608 & 0 \\
\hline \multicolumn{4}{|l|}{ The cost per action } \\
\hline Operation in 2014 & 1.810.429.925.4 & 1.966.001.611.84 & $(155.581 .685 .44)$ \\
\hline \multicolumn{4}{|l|}{ Medium operation } \\
\hline \multicolumn{4}{|l|}{ Direct cost } \\
\hline The cost of material used & 826.936 & 826.936 & 0 \\
\hline The cost of doctor's service & 3.970 .500 & 3.970 .500 & 0 \\
\hline \multicolumn{4}{|l|}{ Anesthesia \& nurse fo M.O } \\
\hline Indirect cost & 619.375 .6 & 583.755 .33 & 35.620 .27 \\
\hline Every operation action cost & 5.416 .811 .6 & 5.381 .191 .33 & 35.620 .27 \\
\hline Total patients & 1.664 & 1.864 & 0 \\
\hline \multicolumn{4}{|l|}{ The cost per action } \\
\hline Operation in 2014 & 9.013.574.502.4 & 8.954 .302 .373 .12 & 59.272 .129 .28 \\
\hline \multicolumn{4}{|l|}{ Major operation } \\
\hline \multicolumn{4}{|l|}{ Direct cost } \\
\hline The cost of material used & 1.083 .423 & 1.083 .423 & 0 \\
\hline \multicolumn{4}{|l|}{ The cost of doctor's service } \\
\hline Anesthesia \& nurse fo M.O & 5.896 .500 & 5.896 .500 & 0 \\
\hline Indirect cost & 929.063 .4 & 601.931 .93 & 327.131 .47 \\
\hline Every operation action cost & 7.910 .986 .4 & 7.583 .854 .93 & 327.131 .47 \\
\hline Total patients & 1.156 & 1.155 & 0 \\
\hline \multicolumn{4}{|l|}{ The cost per action } \\
\hline Operation in 2014 & 9.137.189.292 & 8.759.352.444.15 & 377.836.847.85 \\
\hline \multicolumn{4}{|l|}{$\begin{array}{l}\text { total cost per operation } \\
\text { action, }\end{array}$} \\
\hline Minor,Medium and major & 19.961.193.726.8 & 19.679.666.430.11 & 281.527.290.89 \\
\hline Operation in 2014 & & & \\
\hline
\end{tabular}

Source : made by writer

\section{CONCLUSION AND SUGGESTION}

Based on the description and discussion of the previous chapter, it is concluded that:

1. Cost information generated by the conventional cost accounting used by Royal hospital Surabaya in setting the tariff of operational action services is a distorted cost information, conventional cost accounting imposes an indirect cost to one operation, based on only one 
tariff, improper charge charges, as each type of service consumes indirect costs with different consumption ratios.

2. Activity based costing system (ABC) differentiates the indirect costs to one service operation action, based on the activities that incur indirect costs required in the operation of such operations. Indirect charge loading is done using three cost drivers, which are the number of hours of direct labor, the number of employees, and the number of patients. The $\mathrm{ABC}$ system improves the costing of the traditional cost accounting system by considering that each product or service consumes indirect costs with different consumption ratios. By using more cost drivers, the cost of charging for products or services becomes more accurate

3. Traditional cost accounting that has been used by Royal hospital Surabaya needs to be considered further. This is because the current cost information is less accurate. The ABC system can be considered as a better attenuation to analyze costs, as it allows management to make more correct decisions.

4. Royal Hospital Management understands that in implementing the new system requires additional cost, more time and high commitment. Therefore, the management should analyze the costs and benefits first before implementing the ABC system

\section{References}

Armen F. and Azwar Viviyanti, 2013. Fundamentals of Hospital Financial Management Yogyakarta. Publisher: Gosyen Publishing

Azende Terungwa, 2012, "Practicability of Time-driven Activity-based Costing on Profitability of Restaurants in Makurdi Metropolis of Benue State, Nigeria", journal of contemporary management.

Bustami bastian, Nurlela. 2013. Cost Accounting. Fourth edition. Jakarta: Publisher Mitra Wacana Media Discourse Media

Dan Swenson, Patricia C. Everaert, 2012, "Simulating the Target Costing Process in a Product

Design Environment" AAA Management Accounting Section (MAS) Meeting Paper

Davood Askarany, John A. Brierley, Hassan Yazdifar, 2012, "The effect of innovation on activity based costing adoption", Int. J. Managerial and Financial Accounting, vol. 4, No. 3

G.L. Sharma and P.K. Gupta, 2010. "Activity Based Costing: Strategic Implications for Indian Companies", LBS Journal of Management \& Research

Hartono Bambang, 2010. Marketing Management Hospital. Jakarta: Publisher PT. Rineka Cipta

Juan J. Segovia1 and Amir H. Khataie, 2011, "The Financial Performance Effects of Activity-Based Costing / -

Management in the Telecommunications Industry", Society of Interdisciplinary Business Research (SIBR) 2011

Conference on Interdisciplinary Business Research

Kholifah Nur, 2014, Implementation of based costing system as an alternative in determining the tariff of surgery action at Siti Hajar Hospital Sidoarjo. Surabaya.

Mahmood Shafiee, Golriz Amooee, Yaghoub Farja, 2012, "Developing an Activity-Based Costing Approach to Maximize the Efficiency of Customer Relationship Management Projects"

Marismiati, 2011, Economic and Accounting Information. The role of activity based costing system method in determining the price. Vol.1 No.01 Hal: 55-60

Mulyadi, .February 2014. Cost Accounting twelfth printing. Yogyakarta: YKPN College Management Science Publisher

Mursyidi, 2010. Costing, Just In time, and Activity Based Costing Cost Accounting. Second edition Bandung.: PT.Refika Aditama. 
Pelo gabryela horman, 2012. Implementation of activity based costing on tariff of inpatient services of general hospital of power area in Makassar.

Prima Soofia D. and Bayu Septian K, 2015. Cost Accounting The second edition. Bogor: Publisher

In Media

Raiborn cecily A, Kinney michael R. 2011. Cost Accounting Book I 7th Edition. Jakarta: Publisher Salemba Four

Samryn, 2012. Management Accounting: Cost Information To control Operations and Information Activities. Revised Edition. Jakarta: Publisher Kencana Prenada Media Group

Sarah Gamal, Ehab K.A. Mohamed \& Magda H. Ibrahim, 2012, "A Suggested Framework for the Integration of Activity-Based Costing (ABC) in a Lean Environment to Enhance

Companies Competitive Position - A Case Study in Egypt" AAA 2012 Management Accounting Section (MAS) Meeting Paper

Surjadi Lukman, Sarwiji Bambang. 2013. Cost Accounting Basics Calculation of Cost of Goods. Jakarta: PT.Indeks Syaifullah Hamli, 2014. Practical Book of Cost and Financial Accounting. East Jakarta: Publisher Laskar Aksara.

Witjaksono Armanto, 2013. Cost accounting. Revised Edition. Yogyakarta: Graha Ilmu Publisher 